\title{
Opening Remarks by Davinia Aziz
}

The International Law Commission* exists in organic symbiosis ${ }^{1}$ with the General Assembly through its Sixth Committee. They are bound together in a chapter of Schachter's "invisible college"2 spanning Lake Geneva and the East River. Together, the International Law Commission and the Sixth Committee are responsible for discharging the General Assembly's mandate relating to the "progressive development of international law and its codification", in furtherance of no less than the purposes and principles of the United Nations.

The records of the 1945 San Francisco Conference indicate that drawing the right balance for expressing the General Assembly's international law function was a challenge from the very beginning. The alternative formulations before the drafters of Article 13, paragraph 1(a), of the Charter of the United Nations were: "progressive development" of international law, or "revision" of international law. ${ }^{3}$ The matter went to a vote. In the preparatory work, the following view is recorded just before the vote: “'Progressive development' would establish a nice balance between stability and change, whereas 'revision' would lay too much emphasis on change."

Readers familiar with the statute of the International Law Commission will be aware that the statute specifies different procedural steps for "progressive development" and for "codification". However, article 15 of the statute also contains the provision that the two different concepts are defined only "for

* This contribution is made in my personal capacity, and should not be attributed to the institutions with I am affiliated. I thank Kristi How (International Affairs Division, AttorneyGeneral's Chambers, Singapore) and Marcus Teo (Centre for International Law, National University of Singapore) for allowing me to draw from their own work on the Commission in the course of preparing this contribution.

1 H.E. Ambassador Burhan Gafoor, Permanent Representative of Singapore to the United Nations in New York, "Statement of the Chairperson of the Sixth Committee at the Seventieth Anniversary of the ILC" (New York, 21 May 2018) ("[T] he relationship between the Sixth Committee and the ILC ... is an organic and symbiotic relationship that is based on a common objective, which is to support the progressive development and codification of international law and to strengthen the multilateral rules-based system.")

2 Oscar Schachter, 'The Invisible College of International Lawyers' (1977) 72 Nw U L Rev 217.

3 'Summary report of the twenty-first meeting of Committee II/2', United Nations Conference on International Organization (7 June 1945) Document 848, II/2/46, 177-178.

4 Ibid. 
convenience". ${ }^{5}$ By 1996, the Commission had become explicit about the view that the distinction between the two concepts was "difficult if not impossible to draw in practice."6 The Commission continued: "Flexibility is necessary in the range of cases and for a range of reasons." ${ }^{7}$

Despite these prior acknowledgements of the analytical limits, the conceptual difference between "progressive development" and "codification" continues to preoccupy the Commission's stakeholders across the legal departments of Member States, international courts and tribunals, as well as academia. Refashioned in the rubric of this panel, the Commission's happy medium is assumed to lie somewhere between "identifying existing law" and "proposing new law". In one sense, the preoccupation with the Commission's mandate is not surprising. As lawyers, our professional proclivity is to parse the texts that describe the Commission's mandate. But in another sense, the preoccupation seems to have little practical application in light of the Commission's own abandonment of the distinction between "progressive development" and "codification". Still, sitting in the Sixth Committee room, it is not uncommon to hear Member States asking for the Commission to clarify which elements of its output are "codification", and which elements amount to "progressive development of international law".

I have been asked to write this contribution setting out my reflections on the panel that I was privileged to chair at the Geneva commemorative event. What might we usefully draw from the rich discussions that took place, as the Commission moves into a future where the international order may take shape along lines we do not yet know? Given the practical assimilation of "progressive development" and "codification", why do stakeholders still ask the Commission to account for the difference?

I suggest that continuing conversations about the Commission's mandate of "progressive development", on one hand, and "codification", on the other, are undergirded by fundamental anxieties about the authorship of international law. These anxieties are not new to the codification movement. To some extent, the elements of the travaux préparatoires of the Charter and the statute outlined earlier in this contribution demonstrate this. Travelling yet further back in time, the slim outcome of the 193 o Hague Conference reminds us that

5 Statute of the ILC, UNGA Res 174(II) (21 November 1947) as amended by UNGA Res 485 (V) (12 December 1950); Unga Res 984(X) (3 December 1955); Unga Res 985(x) (3 December 1955) and UNGA Res 36/39 (18 November 1981).

6 ILC, 'Report of the International Law Commission on the work of its forty-eighth session' [1996] II (2) ILC Ybk 1, 86 at para 156.

7 Ibid. 
the codification of international law was not easy even when the delegates were few in number. I would like to draw three points from the panel discussions held in Geneva to illustrate why the debate on the right balance between stability and change in the Commission's mandate remains relevant in 2018 and beyond.

First, as an exercise in reconciling and accommodating different perspectives, "codification" - used now in the sense of transposing international law to writing - presents different challenges today. Some 50 States were represented at the dawn of the United Nations. With successive waves of decolonization and other political reconfigurations - some more or less traumatic than others - we now number 193 Member States of the United Nations. By numbers alone, this fourfold increase is exponential. More remarkable, however, and at the heart of the Commission's contemporary and future challenges, is the sheer diversity of cultures, values, and interests converging at the United Nations. Over seventy years after the San Francisco Conference, the United Nations remains the world's only universal international organization. It is thus a key site for making universal international law.

It is true that the Commission and the Sixth Committee have adapted to changing membership of the United Nations. The number of the members of the Commission has been enlarged three times, with the last and most significant membership reform taking place in $1981 .{ }^{8}$ This was when the Commission's membership was stabilized at 34, with clear rules on geographical distribution, replacing the old "gentlemen's agreements" among regional groups. ${ }^{9}$ Such membership reforms acknowledge the Commission's role as a "microcosm" of the United Nations, as a sort of proving ground for new texts. Seen in this light, the Commission's general preference for working by consensus - thus refraining from explicit disclosure of whether a codification project is more "identifying existing law" or more "proposing new law" - takes on a certain significance. In this image of the Commission as "microcosm", consensus in the Commission aims to facilitate consensus writ large among the United Nations membership. This image of the Commission may also explain why Member States notice when the Commission votes.

But there may be important reasons why Member States might ask the Commission to draw back the curtain on consensus. It is worth remembering that the majority of delegates at Bandung did not, or did not yet, represent Member States of the United Nations. ${ }^{10}$ Bandung's Final Communiqué was

\footnotetext{
$8 \quad$ UNGA Res 36/39 (18 November 1981).

9 Ibid.

10 See the keynote speech by Abdulqawi A. Yusuf in Section 9 of this volume.
} 
framed in the inherited Westphalian vernacular, but expressed the cultures, values, and interests of peoples acquiring agency in the international legal order for the first time. Moreover, speaking in the vernacular of international law does not resolve the inherent tensions underlying participation in an inherited system. A clear technical understanding of how the Commission has approached specific legal issues, especially where those issues are novel and touch on vital interests, can enhance Member States' ability to respond meaningfully to the work products of the Commission. In short, knowing how the Commission regards its own output is helpful to all Member States when they participate, with the Commission, in the collective endeavour of formulating international law. ${ }^{11}$

Second, beyond the United Nations, the Commission's operating environment has changed. Contemporary international law is characterized by a plurality of different actors. Information, including about the Commission and its work, flows freely through submarine fibre optic cables and via satellite to those who can access it. Today, the Commission's audience and interlocutors have expanded to include regional courts, investor-state arbitral tribunals, human rights treaty bodies, and academia, each with their own socio-legal cultures and respective legal standing under classical sources doctrine. Indeed, some of these actors may even overlap in membership with the private codification institutions of the late nineteenth century, which are still active today.

In this pluralist environment, the Commission's institutional role as the codification body of the sole universal international organization comes into sharper focus. Member States react to Commission output through General Assembly action. This reaction, in turn, informs how international lawyers assess the normative weight of the Commission's work. This direct connection to States is unique to the Commission. It is also firmly grounded in the Commission's original institutional design.

Third, the Commission's use of form in its work products has evolved alongside changes in the nature of multilateral treaty-making, ${ }^{12}$ as well as

11 See Antony Anghie, 'Bandung and the Origins of Third World Sovereignty' in Luis Eslava, Michael Fakhri and Vasuki Nesiah (eds), Bandung, Global History, and International Law: Critical Pasts and Pending Futures (CUP 2017).

12 Representative examples include the new architecture of the international climate change regime pursuant to the Paris Agreement and the so-called "mega-regional" economic agreements. On the former, see e.g. Richard B Stewart, Michael Oppenheimer and Bryce Rudyk, 'Building Blocks: A Strategy for near-Term Action within the New Global Climate Framework' (2017) 144 Climatic Change 1; Daniel Bodansky, 'The Legal Character of the Paris Agreement' (2016) 25 RECIEL 142; Lavanya Rajamani, 'Ambition and Differentiation 
broader developments relating to the sites and techniques of global governance. ${ }^{13}$ It is true that the extent to which the Commission has evolved its formal output since the late 199os can sometimes be overstated. The Commission's first projects did not all result in draft articles intended to form the basis for a diplomatic conference. Instead, they included the Nuremberg Principles, formulated at a time when, notwithstanding the judicial activity of the war crimes tribunals, international criminal law was still largely regarded as de lege ferenda, and the initial package of practical measures recommended as ways and means for making the evidence of customary international law more readily available. This early work on customary international law remains salient today.

However, calls for a considered approach when assessing the authority of the Commission's "non-legislative codifications" are valid. ${ }^{14}$ Due attention to "the context and factors militating in favour of the authority of codification conventions and International Law Commission's draft articles, combined with an awareness of the role that these texts may play in the crystallization or formation of new rules"15 ultimately leads to a more robust international law. This responsibility to appraise does not fall on the Commission alone. It applies to all members of the "invisible college" engaged in the "common intellectual enterprise" of applying and developing international law. ${ }^{16}$

In the old League of Nations Council Chamber inaugurated just three years after the outbreak of further war, there was a palpable sense among those present in the Chamber, surrounded by the striking murals of José Maria Sert, that the rules-based multilateral system, established in the late hours of that terrible conflict, stood at a crossroads. Ineta Ziemele's frank contribution highlighted the pluralist and technological realities of contemporary international law. Yifeng Chen's masterful study of the codification movement reminded us that the International Law Commission was not international law's first

in the 2015 Paris Agreement: Interpretative Possibilities and Underlying Politics' (2016) 65 ICLQ 493. On the latter, see e.g. scholarship under the auspices of the MegaReg Project based at the New York University School of Law <https://www.iilj.org/megareg/megaregpapers/>.

13 For an illustrative and succinct exposition of different governance techniques, see Benedict Kingsbury, “Three Models of "Distributed Administration": Canopy, Baobab, and Symbiote' (2015) 13 IJCL 478.

14 Fernando Lusa Bordin, 'Reflections of Customary International Law: The Authority of Codification Conventions and the ILC Draft Articles in International Law' (2014) 63 ICLQ 535.

15 Ibid 566.

16 Schachter (n 2) 217. 
codification institution, while the response by Sean D. Murphy reminded us how the Commission is unique among other codification institutions. The Commission faces complex times in an ambiguous world. ${ }^{17}$ But the Commission's history has shown that it can respond and adapt. There is every reason to look forward to the Commission's continuing positive contribution, in partnership with Member States through the Sixth Committee, to better and inclusive international law.

17 Bilahari Kausikan, Dealing with an Ambiguous World (World Scientific Publishing Co Pte Ltd 2017). 